\title{
Impacts of different concentrations of Copper and Zinc on in vitro responses of Azotobacter chroococum in biomass and nitrogen fixing outputs
}

\author{
Ngumah, C.*; Orji, J.; Akubuokwuoma, J. \& Anoliefoh, U. \\ Federal University of Technology Owerri, Department of Microbiology, P.M.B 1526 Owerri, Nigeria
}

Received April 24, 2018; Accept January 20, 2019

\begin{abstract}
The responses of Azotobacter chroococum for copper and zinc were surveyed in this study. The impacts of different concentrations of copper and zinc on biomass formation and nitrogen fixation of Azotobacter chroococum were investigated. Batch trials were performed under continuous airflow using Jensen's nitrogen free broth, at ambient room temperatures for seven days. Maximum biomass yields of $0.068 \mathrm{OD}_{600}$ units and $0.131 \mathrm{OD}_{600}$ units were recorded at $25 \mathrm{mg} \mathrm{L}^{-1}$ and $200 \mathrm{mg} \mathrm{L}^{-1}$ for copper and zinc amended trials, respectively. Maximum nitrogen fixations of $1.446 \mathrm{ppm}$ and $1.507 \mathrm{ppm}$ were also recorded for copper and zinc amended trials at $12.5 \mathrm{mg} \mathrm{L}^{-1}$, respectively. Statistical analysis revealed strong significant correlations between metal concentrations and nitrogen fixation for copper and zinc amended trials, respectively. Leudeking-Piret modeling showed that nitrogen fixations of Azotobacter chroococum in both copper and zinc amended trials were associated with biomass density.
\end{abstract}

Keywords: Bio-stimulation, kinetic modeling, metal tolerance, micro-nutrients, secondary metabolite, toxicity.

\section{INTRODUCTION}

Metals are a natural part of most environments. However, elevated concentrations of metals arise mainly due to anthropogenic activities, such as: mining, smelting, printing, electroplating, and battery manufacture and disposal. Copper, for instance, is extensively used in herbicides and fungicides. Many of the essential elements required by microbes in low concentrations become toxic to the same microbes at elevated amounts (Nriagu, 1990). Metal toxicity in microorganisms usually manifest in growth inhibition and impairment of specific metabolic processes (Montuelle et al., 1994).

Metals are critical components of many biochemical systems. The lighter metal ions $\left(\mathrm{Na}^{+}, \mathrm{K}^{+}, \mathrm{Ca}^{2+}\right.$, and $\left.\mathrm{Mg}^{2+}\right)$ are used as enzyme co-factors and are important components of ion pumps that drive oxidative phosphorylation and help to maintain osmotic balance within cells (Mills, 2002). Many of the heavy metals are also essential components of biological systems; they are required at low concentrations for growth and biochemical processes. Microorganisms have evolved mechanisms that vary in capacity and specificity to accumulate and tolerate different heavy metals, such as: $\mathrm{Cu}, \mathrm{Zn}, \mathrm{Ni}, \mathrm{Mn}$, and Co in the environment (Gadd, 1990). Metal requirements and tolerance of microbes have been extensively studied by many researchers (Wyszkowska et al., 2013). However, the impact of heavy metals depends on duration of exposure, dose, and type of metal (Paudyal et al., 2007).

Copper is an essential micro-nutrient required as a co-factor for a number of cupro-enzymes, including: amine oxidases, cytochrome c oxidases, laccases, methane monooxygenases, nitrate oxidases, superoxide dismutases, and so on. These proteins are involved in diverse cellular processes, such as energy transduction, iron mobilization, and oxidative stress response (Huertes et al., 2014). Antibacterial properties and toxicity of copper to microorganisms have also been widely documented by researchers (Merroun, 2007).

Zinc is another essential micronutrient, and a component of alcohol dehydrogenase, carbonic anhydrase, and 
carboxypeptidase enzymes. Zinc has been reported by Hassen et al (1998) to be toxic to some bacterial strains even at very low doses, and at the same time highly tolerant by other bacteria. Slater and Capone (1984) and Ahmad et al (2005) in their separate studies reported zinc to be of relatively low toxicity to indigenous soil microbial population.

Azotobacter species are free-living obligate aerobic bacteria dominantly found in soils, which can also grow under low oxygen concentration (Shridhar, 2012). Their population ranges from negligible to $10^{4}$ per gram of soil. However, actual numbers depend upon the physico-chemical and microbial properties of the soil. Azotobacter chroococum is the most prevalent species found, but other species also occur (Kizilikaya, 2009). Other species of Azotobacter include: A. vinelandii, A. beijerinckii, A.paspali, A. armeniacus, A. nigricans, and A. salinestri. Azotobacter species are heterotrophic, and their main property is their ability to fix nitrogen non-symbiotically (Jimenez et al., 2011). Wyszkowska et al (2013) indicated that nitrifying bacteria, symbiotic nitrogen fixing bacteria, and Azotobacter spp. are the most susceptible microorganisms to heavy metal toxicity.

This study investigates the in vitro effects of different concentrations of copper (as $\mathrm{CuSO}_{4} \cdot 5 \mathrm{H}_{2} \mathrm{O}$ ) and Zinc (as $\mathrm{ZnSO}_{4} \cdot 7 \mathrm{H}_{2} \mathrm{O}$ ) on the biomass and nitrogen fixation yields of Azotobacter chroococum. Hence, this study will provide information on levels of copper and zinc tolerances of Azotobacter chroococum as it affects the aforementioned essential bio-activities. Though the concentrations of copper and zinc salts used in this study are unlikely to be found in the natural environment, such concentrations may build up in soils due to different anthropogenic activities, such as agricultural, industrial, and mining activities.

\section{MATERIALS AND METHODS}

\section{Preparation of Azotobacter chroococum inoculum}

Stock samples of Azotobacter chroococcum (Mac12638:11142017) were obtained from MacCliff Research Laboratories (MRL) Ltd., Owerri, Nigeria. This stock sample was authenticated and re-vitalized in Jensen's broth. Stock broth culture of $A$. chroococum was prepared. To prepare stock broth culture of $A$. chroococum: a sterile wire loop was used to introduce $A$. chroococum from the Jensen's agar slant stock to sterile Jensen's (nitrogen free) broth (SRL, India), and incubated at prevailing room temperatures for 5-7 days under continuous airflow. Biomass growth was indicted by increased turbidity of the broth. From this stock broth, 0.5 McFarland standards were prepared (Kizilkaya, 2009).

\section{Toxicity tests}

$200 \mathrm{mg} \mathrm{L}^{-1}, 100 \mathrm{mg} \mathrm{L}^{-1}, 50 \mathrm{mg} \mathrm{L}^{-1}, 25 \mathrm{mg} \mathrm{L}^{-1}, 12.5 \mathrm{mg}$ $\mathrm{L}^{-1}$, and $0 \mathrm{mg} \mathrm{L}^{-1}$ concentrations of sterile $\mathrm{CuSO}_{4}$ and $\mathrm{ZnSO}_{4}$ solutions, respectively, were prepared in half strength Jensen's broth (Mills, 2002). The initial concentration of $12.5 \mathrm{mg} \mathrm{L}^{-1}$ was chosen arbitrarily, while subsequent concentrations were double folds of the previous concentration. Then $0.1 \mathrm{ml}$ aliquot of 0.5 McFarland standard of $A$. chroococcum was added to $9.9 \mathrm{ml}$ of each of the above sterile $\mathrm{CuSO}_{4}$ and $\mathrm{ZnSO}_{4}$ concentrations, respectively. This set up was incubated for 7 days at prevailing room temperatures under continuous airflow in a sterile chamber plugged to a Airfree T800 Filterless Air Purifier (USA). The optical density at $600 \mathrm{~nm}\left(\mathrm{OD}_{600}\right)$ (using model 722 visible spectrophotometer, manufactured by Shanghai Third instrument Factory, China), nitrate-N concentration, and amino-N concentration of each test were measured at days 0 and 7, respectively (Paudyal et al., 2007).

\section{Estimation of nitrate nitrogen and amino nitrogen}

Broth culture experiments were analyzed for nitrate nitrogen $\left(\mathrm{NO}_{3}-\mathrm{N}\right)$ and amino nitrogen (Amino- $\left.\mathrm{N}\right)$ at the beginning (Day 0) and at the end (Day 7) of the trials. Nitrate-N concentration was determined by Cataldo's method as described by Cataldo et al (1974): $2.5 \mu \mathrm{l}$ of sample solution was taken into a $1.5 \mathrm{ml}$ Eppendorf tube, and $10 \mu \mathrm{l}$ of salicylic acid-sulfate solution (500 $\mathrm{mg}$ of salicylic acid was dissolved in $10 \mathrm{ml}$ of concentrated sulfuric acid) was mixed and kept for 20 minutes. Then, $250 \mu \mathrm{l}$ of $2 \mathrm{M} \mathrm{NaOH}$ solution $(8.00 \mathrm{~g}$ of $\mathrm{NaOH}$ was dissolved in $100 \mathrm{ml}$ of water) was mixed and kept for 20 minutes. $200 \mu \mathrm{l}$ of the reaction solution was put in a 722 visible spectrophotometer and the absorption at $410 \mathrm{~nm}$ was measured. Standard solution was made by dissolving $42.5 \mathrm{mg}$ of $\mathrm{NaNO}_{3}$ in $100 \mathrm{ml}$ of water, which contains $5 \mathrm{mM}$ nitrate (70 $\left.\mathrm{mg} \mathrm{N}{ }^{-1}\right)$. Diluted solutions $(0,1,2,3,4,5 \mathrm{mM})$ were used for the calibration and plotting of standard curve.

Amino-N concentration was determined by ninhydrin method (Herridge, 1985): $2.5 \mu \mathrm{l}$ of sample solution was taken into a $1.5 \mathrm{ml}$ Eppendorf tube, and $75 \mu \mathrm{l}$ of citrate buffer (5.6 $\mathrm{g}$ of citrate and $2.13 \mathrm{~g}$ of $\mathrm{NaOH}$ was dissolved in $100 \mathrm{ml}$ of water) was mixed. Afterwards, $60 \mu \mathrm{l}$ of ninhydrin solution (958 $\mathrm{mg}$ of ninhydrin and $33.4 \mathrm{mg}$ of ascorbate was dissolved in 3.2 $\mathrm{ml}$ of water and filled up to $100 \mathrm{ml}$ with methoxyethanol in a flask. The flask was secured with its cork and heated at $100^{\circ} \mathrm{C}$ for 20 minutes in a hot air oven (Quincy Hydraulic Gravity Convection Oven, USA.). Then, $300 \mu$ l ethanol was added and cooled to room temperature for 10 minutes. $200 \mu \mathrm{l}$ of the reaction solution was put in a 722 visible spectrophotometer and the absorption at $570 \mathrm{~nm}$ was measured. Standard solution was made by dissolving $66.1 \mathrm{mg}$ of asparagine (or $70.1 \mathrm{mg}$ of asparagine monohydrate) plus $73.1 \mathrm{mg}$ glutamine in $100 \mathrm{ml}$ of water, which contains $5 \mathrm{mM}$ asparagine $+5 \mathrm{mM}$ glutamine (280 $\left.\mathrm{mg} \mathrm{N} \mathrm{L}^{-1}\right)$. Diluted solutions $(0,28,56,84,112,140 \mathrm{mg} \mathrm{N}$ $\left.\mathrm{L}^{-1}\right)$ were used for the calibration and plotting of standard curve.

\section{Determination of specific growth rate}

The specific growth rate of Azotobacter chroococum was determined using the formula given by Stanier et al (1985): 
Specific growth rate $=\underline{\log \mathrm{OD}_{1}-\log \mathrm{OD}_{0}} \times 2.303$

$$
\mathrm{T}_{1}-\mathrm{T}_{0}
$$

Where,

$\log \mathrm{OD}_{1}=\log$ value of optical density (OD) of culture at time $\mathrm{T}_{1}$ days

$\log \mathrm{OD}_{0}=\log$ value of optical density (OD) of culture at time $\mathrm{T}_{0}$ days.

\section{Estimation of fixed nitrogen}

The amount of nitrogen fixed was estimated with the formula:

\section{Nitrogen fixed $=\mathbf{N}-\mathbf{N}_{\mathbf{0}}$}

Where,

$\mathrm{N}=$ the total concentrations of (nitrate nitrogen + amino nitrogen) in culture medium after incubation.

$\mathrm{N}_{0}=$ concentrations of (nitrate nitrogen + amino nitrogen) in culture medium before incubation.

\section{Estimation of nitrogen fixation rate}

Nitrogen fixation rate was estimated using the formula:

Nitrogen fixation rate $=\underline{\mathrm{N}-\mathrm{N}_{\underline{0}}}$

$$
\mathrm{T}-\mathrm{T}_{0}
$$

Where,

$\mathrm{N}-\mathrm{N}_{0}=$ Nitrogen fixed

$\mathrm{T}-\mathrm{T}_{0}=$ incubation period

\section{Statistical analysis}

All measurements were made in triplicate, and values reported as means of triplicate values. Student $t$ tests and Pearson's correlation analysis for all possible variable pairs were estimated using Minitab 17 software. Significance was taken at $5 \%$ level of significance $(\mathrm{p} \leq 0.05)$.

\section{Mathematical modeling}

The Luedeking-Piret model was applied to analyze product synthesis (nitrogen fixation) kinetics, using Curve Expert Professional 2.4.

\section{RESULTS AND DISCUSSION}

After 7 days incubation, the control experiment (trial without any metal amendment) gave a biomass yield of $\mathrm{X}_{\mathrm{o}}=$ $0.042 \mathrm{OD}_{600}$ units and a nitrogen fixation yield of $\mathrm{P}_{\mathrm{o}}=0.847$ ppm. Maximum biomass concentration $\left(\mathrm{X}_{\max }\right)$ of $0.068 \mathrm{OD}_{600}$ units and $0.131 \mathrm{OD}_{600}$ units occurred at $25 \mathrm{mg} \mathrm{L}^{-1} \mathrm{CuSO}_{4}$ and $200 \mathrm{mg} \mathrm{L}^{-1} \mathrm{ZnSO}_{4}$ concentrations, respectively (Figure 1). While, maximum nitrogen fixations $\left(\mathrm{P}_{\max }\right)$ of $1.446 \mathrm{ppm}$ and $1.507 \mathrm{ppm}$ occurred at $12.5 \mathrm{mg} \mathrm{L}^{-1} \mathrm{CuSO}_{4}$ and $12.5 \mathrm{mg} \mathrm{L}^{-1}$ $\mathrm{ZnSO}_{4}$ concentrations, respectively (Figure 2).
Copper enhanced biomass growth of A. chroococum progressively at $12.5 \mathrm{mg} \mathrm{L}^{-1}$ and $25 \mathrm{mg} \mathrm{L}^{-1} \mathrm{CuSO}_{4}$ concentrations, while at $50 \mathrm{mg} \mathrm{L}^{-1}, 100 \mathrm{mg} \mathrm{L}^{-1}$, and $200 \mathrm{mg} \mathrm{L}^{-1}$ $\mathrm{CuSO}_{4}$ concentrations progressively inhibited biomass growth (Figure 1). At $50 \mathrm{mg} \mathrm{L}^{-1} \mathrm{CuSO}_{4}$ concentration, though biomass yield was less than that of the control experiment, nitrogen fixation yield surpassed that of the control experiment. This indicates that increased biomass yield does not always imply increased bio-product output, as also reported by Orji et al (2018). A maximum growth rate $\left(\mu_{\max }\right)$ of $0.076 \mathrm{OD}_{600}$ units day $^{-1}$ at $25 \mathrm{mg} \mathrm{L}^{-1} \mathrm{CuSO}_{4}$ concentration was observed for $A$. chroococum in these trials. Similar inhibitory activities of copper on biomass growth and nitrogen fixation of diazotrophs have been also been reported by: Slater and Capone (1984), El-Ghamry et al (2000), Zhan and Sun (2012). Wyszkowska et al (2013) reported that Azotobacter species are among the most susceptible microorganisms to heavy metals.

As all five zinc metal concentrations tested enhanced the biomass of A. Chroococum progressively (Figure 1), a maximum growth rate $\left(\mu_{\max }\right)$ of $0.170 \mathrm{OD}_{600}$ units day ${ }^{-1}$ (at $200 \mathrm{mg} \mathrm{L}^{-1}$ of $\mathrm{ZnSO}_{4}$ ) was observed for $A$. Chroococum. Zinc (as $\mathrm{ZnSO}_{4}$ ) tremendously improved biomass growth of $A$. Chroococum. Its specific growth rate was increased approximately 20 times (when compared to the control) at the lowest $\mathrm{ZnSO}_{4}$ concentrations $\left(12.5 \mathrm{mg} \mathrm{L}^{-1}\right)$ tested. On the other hand the copper increased specific growth rate of $A$. Chroococum only about three times (when compared to the control) at $12.5 \mathrm{mg} \mathrm{L}^{-1}$ of $\mathrm{CuSO}_{4}$. Though the specific growth rate of $\mathrm{A}$. Chroococum progressively increased from $0 \mathrm{mg} \mathrm{L}^{-1}$ to $200 \mathrm{mg} \mathrm{L}^{-1} \mathrm{ZnSO}_{4}$ concentrations, the rate of increments of specific growth rates progressively waned between consecutive increments of $\mathrm{ZnSO}_{4}$ concentrations. Student's t test revealed significant difference $(p<0.05)$ in the specific growth rates between trials amended with copper and zinc. Pearson's correlation revealed a very strong positive correlation $(r=0.878)$ between the specific growth rates of the copper and zinc amended trials. Though, $A$. chroococum significantly differed in its biomass value responses to copper and zinc, its pattern of responses was basically similar to both copper and zinc.

Nitrogen fixation by $A$. chroococum was elevated nonprogressively at $12.5 \mathrm{mg} \mathrm{L}^{-1}, 25 \mathrm{mg} \mathrm{L}^{-1}$, and $50 \mathrm{mg} \mathrm{L}^{-1} \mathrm{CuSO}_{4}$ concentrations, and abated progressively at $100 \mathrm{mg} \mathrm{L}^{-1}$ and 200 $\mathrm{mg} \mathrm{L}^{-1} \mathrm{CuSO}_{4}$ concentrations (Figure 2). For $\mathrm{ZnSO}_{4}$, nitrogen

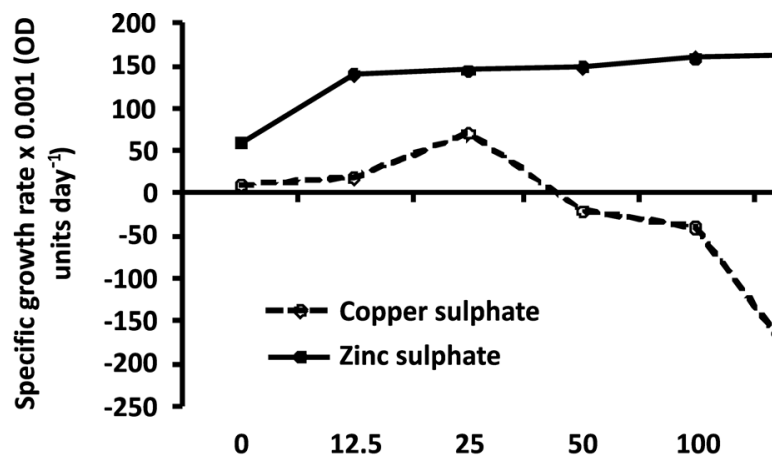

Figure 1. Growth rates of Azotobacter chroococum at different concentrations of copper and zinc salts. 
fixation was enhanced only at $12.5 \mathrm{mg} \mathrm{L}^{-1}$ concentration, while subsequent higher concentrations tested showed progressive reductions in the amounts of nitrogen fixed during the trial.

Pearson's correlation analysis at $5 \%$ level of probability revealed significantly $(\mathrm{p}<0.05)$ : very strong indirect correlation between copper concentrations and biomass yields $(r=-0.826)$; very strong indirect correlation between copper concentrations and nitrogen fixations $(\mathrm{r}=-0.911)$; very strong and indirect correlation between copper concentrations and specific growth rates $(\mathrm{r}=-0.927)$; and a fairly strong and indirect correlation between copper concentrations and nitrogen fixation rates $(r=-0.642)$. For zinc trials: a strong direct correlation was seen between zinc concentrations and biomass growths $(\mathrm{r}=0.705)$; a very strong indirect correlation between zinc concentrations and nitrogen fixations $(r=-0.869)$, and fair positive but insignificant $(\mathrm{p}>0.05)$ correlations between zinc concentrations and specific growth rates $(r=0.565)$; and a very weak direct and insignificant correlation between zinc concentrations and nitrogen fixation rates $(r=0.208)$.

Kinetic associations between cell mass and nitrogen fixation of Azotobacter chroococum at different metal (copper and zinc) concentrations were analysed using the Leudeking-Piret model.

$$
\mathbf{r}_{\mathrm{fp}}=\boldsymbol{\alpha \mathbf { r } _ { \mathrm { fx } }}+\boldsymbol{\beta} \mathbf{x}
$$

Where,

$\mathrm{r}_{\mathrm{fp}}=$ rate of product formation

$\mathrm{r}_{\mathrm{fx}}=$ rate of biomass formation

$\alpha=$ coefficient of proportionality between the rate of product formation and growth rate (ppm//OD-units)

$\beta=$ coefficient of proportionality between the rate of product formation and biomass concentration ( $\mathrm{ppm} / \mathrm{OD}-$ units day $\left.^{-1}\right)$.

According to this model, the product formation rate (nitrogen fixation rate) depends linearly upon the growth rate and the cell mass concentration. A linear regression plot of nitrogen fixation rate against specific growth rate generated $\alpha=0.0010156$ and $\beta=0.14032$ for copper amended trials (Figure 3). Since, $\alpha>0$ and $\beta>0$, then it implies that in this trial, nitrogen fixation was associated with both biomass growth and biomass concentration of A. chroococum (Ramakrishnan et al., 2015). However, since

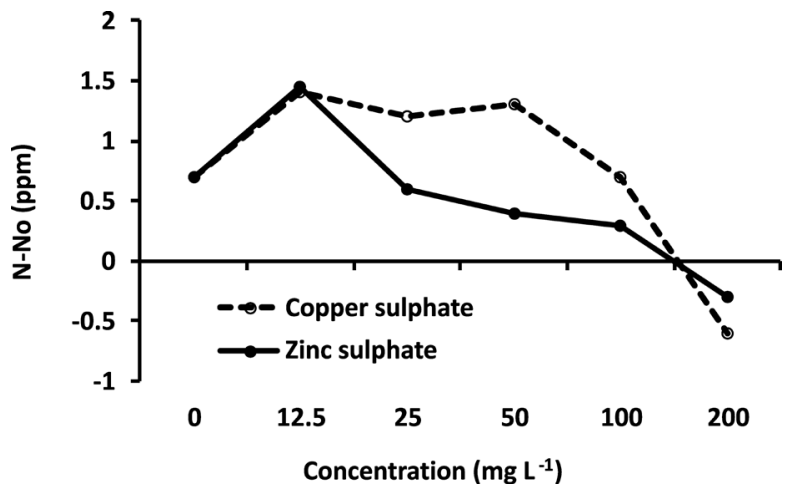

Figure 2. Nitrogen fixation of Azotobacter chroococum at different concentrations of copper and zinc salts. $\beta(0.14032)$ is far greater than $\alpha(0.0010156)$, and also since the value of $\alpha=0.0010156$ is not significant at 0.01 level of significance, one may infer that nitrogen fixation yields in these trials were more significantly influenced by the non-growth associated constant ( $\beta$ ), or otherwise insignificantly determined by the growth associated constant, $\alpha$ (Ahmad et al., 2011; Thierie, 2013). A linear regression plot of nitrogen fixation rate against specific growth rate for zinc trials gave $\alpha=-0.00054363$ and $\beta=0.15508$ (Figure 4). Since, $\alpha<0$ and $\beta>0$, it implies that nitrogen fixation in the zinc amended trial was associated with biomass density rather than with biomass growth.

The Leudeking-Piret linear regression plots gave $\mathrm{R}^{2}=$ $0.8337(\mathrm{p}=0.01)$ for copper amended trials, and $\mathrm{R}^{2}=0.1524$ $(p=0.44)$ for zinc amended trials (where, $R^{2}=$ coefficient of determination). The high $\mathrm{R}^{2}$ and low $\mathrm{p}(\mathrm{p}<0.05)$ values of the copper amended trials indicate that the Leudeking-Piret model explains about $83.37 \%$ of variation in the biomass growth and nitrogen fixation by $A$. chroococum. Since $\mathrm{R}^{2}$ values lies between 0 and 1 , and a value $\geq 0.75$ indicates the level of goodness of fit of the model (Keur and Satyanarayana, 2005), hence one conclude that the Leudeking-Piret model is an appropriate kinetic model for analyzing the copper amended trial. However, the low $\mathrm{R}^{2}$ and high $p(p>0.05)$ values of the zinc amended trial plot reveal that Leudeking-Piret model does not sufficiently explain how biomass of $A$. chroococum accounts for the amount of nitrogen fixed. Hence, in the zinc amended trials other factors (probably not monitored in this study) such as the presence of other substances, for example nutrients (whether micro or macro),

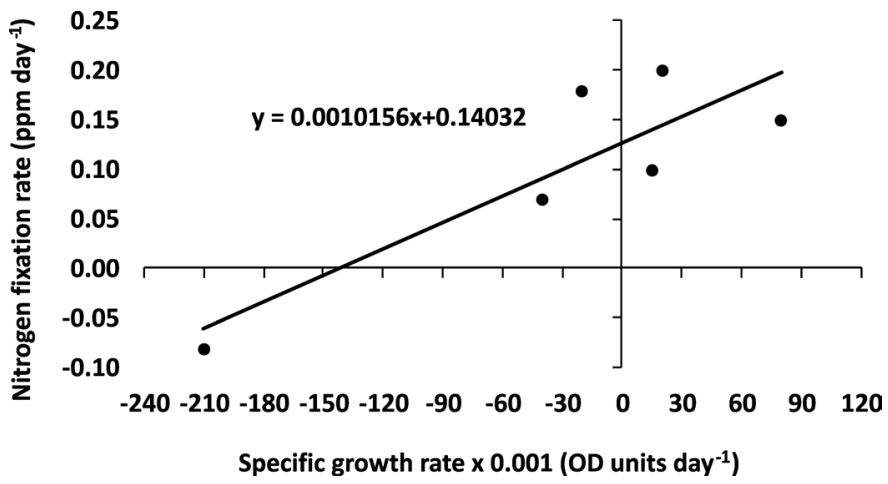

Figure 3. Leudeking-Piret model of Azotobacter chroococum for copper sulphate concentrations.

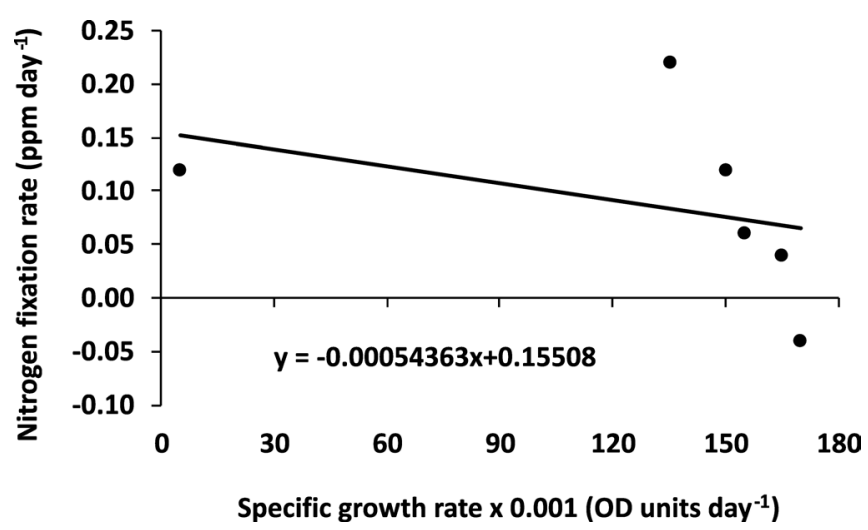

Figure 4. Leudeking-Piret model of Azotobacter chroococum for zinc sulphate concentrations. 
inhibitors, etc. may have been significant extrinsic factors in determining the quantity of nitrogen fixed by $A$. chroococum. Furthermore, the insignificant correlations $(p>0.05)$ between $\mathrm{ZnSO}_{4}$ concentrations and: biomass growth, specific growth rate, and nitrogen fixation, of $A$. chroococum, (though, does not explain why the Leudeking-Piret model falls short in accounting for the kinetics of the zinc amended trial) go on to affirm the disparities observed between the said parameters.

\section{CONCLUSIONS}

Data obtained in this study indicate that copper at low concentrations enhanced both biomass formation and nitrogen fixation of $A$. chroococum; however at higher concentrations copper abated both biomass formation and nitrogen fixation. For zinc, all the concentrations assayed in this study enhanced biomass progressively, however only $12.5 \mathrm{mg} \mathrm{L}^{-1} \mathrm{ZnSO}_{4}$ concentration enhanced nitrogen fixation. Nitrogen fixations in both copper and zinc trials were significantly associated with biomass density.

\section{REFERENCES}

AHMAD F, JAMEEL AT, KAMARUDIN MH, MEL M. 2011. Study of growth kinetics and modeling of ethanol production by Saccharomyces cerevisae. Afr. J. Biotechnol. 16(81):1884218846. http://dx.doi.org/10.5897/AJB11.2763

CATALDO KA, SCHRADER LE, YOUNGS V.L. 1974. Analysis by digestion and colorimetric assay of total nitrogen in plant tissues high in nitrate. Crop Science, 14:845-846. http://dx.doi. org/10.2135/cropsci1974.0011183X001400060024x

EL-GHAMRY, A.M., SUBHANI, A., MOH'D, W., CHANGYONG, H., ZHENGMIAO. 2000. Effects of copper toxicity on soil microbial biomass. Pak. J. Biol. Sci. 3(6): 907-910. http://dx.doi. org/10.3923/pjbs.2000.907.910

GADD G.M. 1990. Heavy metal accumulation by bacteria and other microorganisms. Experentia 46(8):834-840. http://dx.doi. org/10.1007/BF01935534

HASSEN, A., SAIDI, N., CHERIF, M., BOUDDABOUS, A. 1998. Resistance of environmental bacteria to heavy metals. Bioresour. Technol. 64:7 - 15 .

HERRIDGE, D.F. 1984. Effect of nitrate and plant development on the abundance of nitrogen solutes in root-bleeding and vacuumextracted exudates of soybean. Crop Sci. 24:173-179. http:// dx.doi.org/10.2135/cropsci1984.0011183X002400010041x

HOLT, J.G, KREIG, N.R., SNEATH, P.H., STALEY, J.T., WILLIAMS, S.T., (EDS.) 1994. Bergey's Manual of Determinative Bacteriology, 9th edn. Williams \& Wilkins.

HUERTAS, M.J., LÓPEZ-MAURY, L., GINER-LAMIA, J., SÁNCHEZ-RIEGO, M., FLORENCIO, F.J. 2014. Metals in cyanobacteria: analysis of the copper, nickel, cobalt and arsenic homeostasis mechanisms. Life 4, 865-886.

JIMENEZ, D.J., SALVADO, J., MARTINEZ, M. 2011. Characterization of free nitrogen fixing bacteria of the genus
Azotobacter in organic vegetable-grown Colombian soils. Braz. J. Microbiol. 42:846 - 858.

KEUR, P. AND SATYANARAYANA, T. 2005. Production of cell-bound phytase by Pichia anomala in an economical cane molasses medium: optimization using statistical tools. Process Biochem. 40:3095-3102.

KIZILKAYA R. 2009. Nitrogen fixation capacity of Azotobacter spp. strains isolated from soils in different ecosystems and relationship between them and the microbiological properties of soils. J. Environ. Biol. (1): 73-82.

MERROUN,M. 2007. Interactions between metals and bacteria: fundamental and applied research. Communicating Current Research and Educational Topics and Trends in Applied Microbiology.

MILLS, A.L. 2002. Metal requirements and tolerance. In: Hurst CJ, Crawford RL, Knudsen GR, Mcinerney MJ, Stetzenbach LD, eds. Manual of Environmental Microbiology. ASM Press: 456465.

MONTUELlE, B., LATOUR, X., VOLAT, B., GOUNOT, A. 1994. Toxicity of heavy metals to bacteria in sediments. Bull. Environ. Contam. Toxicol. 53(5):753-8.

NRIAGU, J.O. 1990. Global metal pollution: poisoning the biosphere? Environment 32:6-11, 218-233.

ORJI, J., NGUMAH, C., ASOR, H., ANUONYEMERE, A. 2018. Effects of cobalt and manganese on biomass and nitrogen fixation yields of a free-living nitrogen fixer-Azotobacter chroococum. Eur. J. Biol. Res. (1):7-13.

PAUDYAL S.P., ARYAL, R.R., CHAUHAN, S.V., MAHESHWARI, D.K. 2007. Effect of heavy metals on growth of Rhizobium strains and symbiotic efficiency of two species of tropical legumes. Sci. World J. 5(5): 27-32.

RAMAKRISHNAN, V., GOVEAS, L.C., HALAMI, P.M., NARAYAN, B. 2015. Kinetic modeling production and characterization of an acidic lipase produced by Enterococcus durans NCIM5427 from fish waste. J. Food Sci. Technol. 52(3):1328-1338

SHRIDHAR, B.S. 2012. Review: nitrogen fixing micro-organisms. Int. J. Microbiol. Resources, 3(1):46-52.

SLATER, J. AND CAPONE, D. 1984. Effects of metals on nitrogen fixation and denitrification in slurries of anoxic salt-marsh sediment. Mar. Ecol. Prog. Series, 18:89 - 95.

STANIER, R.Y., ADELBERG, E.A., INGRAHAM, J.L. 1985. Microbial growth. In: General Microbiology. MacMillan Publication, London: 273-293.

THIERIE, J. 2013. Computing and interpreting specific production rates in a chemostat in steady state according to the LeudekingPiret model. Biotechnol. Appl. Biochem. 169:477-492.

WYSZKOWSKA, J., BOROWIK, A., KUCHARSKI, M., KUCHARSKI, J. 2013. Effect of cadmium, copper and zinc on plants, soil microorganisms and soil enzymes. J Elementol. 769796. http://dx.doi.org/10.5601/jelem.2013.18.4.455

ZHAN, J. AND SUN, Q. 2012. Diversity of free-living nitrogenfixing microorganisms in the rhizosphere and non-rhizosphere of pioneer plants growing on wastelands of copper mine tailings. Microbiol. Res. 167: 157-165. http://dx.doi.org/10.1016/j. micres.2011.05.006 